\title{
ANTECEDENTS AND OUTCOMES OF KNOWLEDGE MANAGEMENT PRACTICES: EVIDENCE FROM PAKISTAN
}

\author{
MUHAMMAD ARIF \\ MUZAMMAL ILYAS SINDHU \\ Bahria University, Islamabad, Pakistan \\ INAYAT ULLAH KHAN \\ NUST, Islamabad, Pakistan \\ SYEDA FAIZA UROOJ \\ Federal Urdu University, Islamabad, Pakistan
}

\begin{abstract}
The purpose of the study was to examine antecedents and outcomes of knowledge management practices in education sector of Pakistan. Leadership, culture, technology and competence development were used as antecedents. The data were collected from public and private sector universities and NGOs across Rawalpindi/Islamabad region. The results indicated that leadership has positive impact on knowledge management practices. Similarly, culture, technology and competence development positively impact the knowledge management practices as well. Ultimately, the results concluded that knowledge management practices positively and significantly impact organizational performance. Study limitations and future research directions are also discussed.
\end{abstract}

\section{INTRODUCTION}

Knowledge management has become critical in the contemporary business environment that mandates continuous adaptation and change by organization, and requires employees to strive to improve their company's work process. It can help organizations to gain competitive advantage and improve organizational performance. It's thereason that knowledgemanagement literature has been growing in last two decades. Because it is a burning issue of today's world of management and effective professionals had always recognized its importance. These professionals enlightened not only professional techniques, primary skills, best methods, learning organizations, and business storage but they also recognized that their organization's key resources are organizational structures, business, and its individuals, their knowledge and abilities (Quintas, 1999).

With continuous toil, resultantly, these professionals concluded that the best technological innovation are necessary for monopolies in specific marketplaces but many companies have recently come to know that maintainable source of the very competitive knowledge is also important. Actionable knowledge represents the appropriate view and details being available in the right place, at the proper time, in the right perspective and in the right way to anyone who can carry it to make better decisions (Harrison and Leitch, 2000). Knowledge is the key source in brilliant selection, predicting, style, preparing, research, assessment, and user-friendly outcome creation. It is established and distributed between personal and combined thoughts of team or group. It does not develop out of data source but, is modified with experience, achievements, breakdowns, and discovering eventually.

In a learning company, management remains careful to visualize problems and to present alternative solutions to overcome all these issues. Organization develops strategies to strengthen necessary skills; essential for the development of the company. Similarly, difference in group features impact on desired outcomes for advancement and business efficiency. It is, therefore, imperative to assess the effect of group features on the comprehension management system, advancement and company efficiency. The major issues which have been raised from above discussion are to check that which type of knowledge practices are important for organizational performance. The main problem which can be concluded is that whether knowledge practices will improve the organizational performance, and at what level.

This study will provide a profound benefit to the all level managerial personnel. It will help identify crucial 
factor of business culture as a component of belief in workers and will make policies according to most suitable in a diversified individuals. The more people believe in each other, the more likely is the result that they could socialize and share their knowledge with each other. This study should be a useful record in the work of alignment of the organization towards efficiency where knowledge workers perform a critical role; henceforth, it would be truly appropriate for the organization to make use of it. Creation of environment and knowledge is an important part of socio-economic factors, emotional aspect and human management methods.

\section{LITERATURE REVIEW}

Knowledge management (KM) provides the significant concerns of business adoption, success, and experience in the face of progressively more discontinuous ecological change. Ahmad, Fiaz and Shoaib (2015) indicated that knowledge management activities i.e. knowledge acquisition, knowledge conversion, knowledge application and knowledge protection, result in provision of quality services to customers, high customer satisfaction, efficiency in resource utilization, more profits and overall improved organizational performance. Zack, Mckeen and Singh (2009) founded that KM practices were found to be directly related to organizational performance which, in turn, was directly related to financial performance. There was no direct relationship found between KM practices and financial performance. A different set of KM practices was associated with each value discipline (i.e. customer intimacy, product development and operational excellence).

Primarily, it represents business procedures that search for a complete mixture of data and details producing a potential of details for technological innovation, and modern potential of human beings (Malhotra, 1997). Wong (2005) mentioned that many companies in the international market, especially the bigger ones, are aware of this, and they try to discover the area expertise management in order to strengthen and maintain their competition. Bethel (1998) suggests that the good leadership has the ability to make an impression on others. Bohn (2002) recommend that leadership is a source to create a clear perspective, and provide self-confidence to their helpers. It is possible with the help of cooperation and interaction with details. Heilbrun (1994) said that the leadership ideas have three steps for conversation. The first thing is to determine management. The second phase is the mindset of management which has to be made up at the idea of innovator mindset. The third phase is to focus on how they synchronize and work with individuals and issues effectively and are contented with the issues between management and helpers (The idea of leadership contingency). Burns (1978) and Bass (1997) suggest that on the platform of lately released leadership idea, we can split the leadership concepts into agreement leadership and change leadership.

Kim \& Shim (2003) and Pounder (2001) recommend that the agreement leadership is consumed by needs, which concentrates on essential and sideline fulfillment against needs. It has a conventional procedure to management and its aim is to sustain the balance of the company. A company's drawback to change to deal with the ecological demands and ambivalence is a situation for which many possible condensate and alternatives are provided. Schein $(1985,1992)$ recommended a strategy to this problem that is very well-known and commonly mentioned. According to that theory, the company's culture causes drawback at a main level which necessitates changes. Company's past and present logic, encounters, viewpoint, and principles that carry it together, and is indicated in its self-image, inner technicalities, relationships with the outside world, and upcoming objectives is known as culture of a company. There are two kinds of management: one of them is developing a culture when the others are developing categories and companies. When the culture is designed then they find the requirements for leadership and then choose who the innovator is. When the culture becomes malfunctioned, it is the particular procedure of leadership to comprehend the running and malfunctioned aspects of the current culture and to deal with social progression and adjustment in such a way that the team is still available in a changing atmosphere (Schein, 1992).

Technical impulsion has changed the way we convey, store, share and exchange data at low cost and broadband. The option on every employee's pc has made more details rapidly available than it ever was. IT systems enable the Integration of details and Knowledge in the organization as well as the development, transfer, storage and safe-keeping of the company's Knowledge resource. When the company is experiencing inadequate results, there is discontentment with these resources (Rigby, 2001; Rigby \& Bilodeau, 2005) which are committing an affordable sum of money and attempt in the employing of ICT-based KM programs (Rigby \& Bilodeau, 2007). Technical innovation can be seen in two significant ways from a new institutional point of view. According to Rowan (1977), Technical innovation is the "core" that discloses the way in which work is actually done. So it should be secured and stored from business demands and misconceptions. Important sizing of the company can be showed by the technical innovation, and the institutional stage helps to protect this primary from 
exterior demands. Thompson (1967) is comfortable with the fact that the company's part is to adhere to logical misconceptions and a technological stage which has the part of accomplishing the instrumental operation of the company such as generating products or accomplishing services.

Mark McClelland presents the idea of "competency" into the HR literature. McClelland's theory mentioned that the job analytic techniques to employees choice was the offer to test for experience, intellect examining and the conventional job analytic techniques to employees choice and the growing discontentment. Ulrich (1998) states that through abilities, individuals' expense as part of intelligent expense can be observed. Bontis and Fitzenz (2002) suggested that comprehension, ability, and experience of employees symbolize from individuals expense, whereas, codified comprehension, and relational expense symbolizes comprehension included in the business value string through structural expense.

Competencies elements consist of the effectiveness of knowledge and skills, choice, drive and their use of will. In the old economic climate, due to mentioned group quantity, attentiveness and efficiency, the mental part of competencies were primarily fostered. The mental part of competencies leads towards the making of satisfied individuals.

\section{Knowledge Management Practices \& Organizational Performance}

Lin et al. (2008) state the degree to which organizational objectives are met and measured by organizational performance. Matin et al. (2009) contend that organizational performance can be measured by worker performance and value addition and it can enhanced by specifying the organizational culture and procedures to serve customers. Knowledge has to be used to support the firm's processes and to impact organizational performance. According to Cohen and Levinthal (1990); Seleim and Khalil (2007); Zahra and George (2002), the knowledge gained by the organization can be utilized to transform potential capability into a realized and dynamic capability that improves organizational performance.

An investment in knowledge always plays an excellent role in the development of the company. Increased realization of knowledge as the core competence (Prahlad \& Hamel 1990), coupled with recent advances in information technology such as intranets and the World Wide Web, has increased organizational interest in the topic of knowledge management. Examples of known knowledge management initiatives include Andersen's Knowledge Xchange, Booz Allen \& Hamilton's Knowledge On-
Line, CAP Gemini's Knowledge Galaxy, Ernst \& Young's Center for Business Knowledge and Monsanto's Knowledge Management Architecture.

\section{FRAMEWORK}

On the basis of literature review, some of the variables have been framed which are depicted in the schematic diagram

FIGURE 1

Schematic Diagram

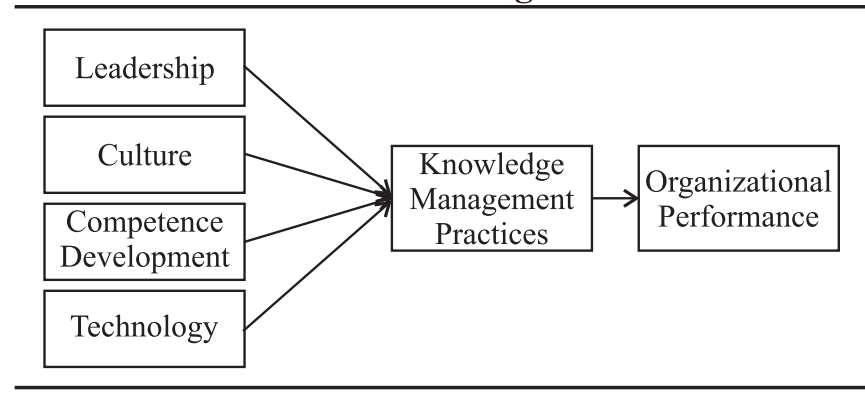

\section{Hypotheses}

In view of the variable established in the schematic diagram, some of the hypotheses have been made as under:

\section{Hypothesis 1. Leadership has significant effect on Knowledge Management Practices.}

Hypothesis 2. Organizational culture has significant effect on Knowledge Management Practices.

Hypothesis 3. Competence Development has significant impact on Knowledge Management Practices.

Hypothesis 4. Technological advancement has significant impact on Knowledge Management Practices.

Hypothesis 5. KnowledgeManagementPractices has significant impact on Organizational Performance.

\section{METHODOLOGY}

\section{Population \& Sampling Frame}

Population of this research has been placed at the workers of corporate industry including public and private universities. NGO's, along with its offices in 
Islamabad and Rawalpindi areas in Pakistan are also made part of the research. Thus, the example shape includes the upper and middle management of the stated agencies. List of the example size includes the 500 employees of the aforesaid agencies in various areas in management levels.

\section{Sample \& Respondents}

The research would be implemented in business industry of Pakistan. Random choosing methods were used for the submission of the surveys. Five hundred (500) surveys were spread among the workers of business industry containing universities of government and semigovernment status, NGOs, etc. The focused population for this research is experts (managers, instructors and managing personnel of the aforesaid industries) who have been with the company for more than three years.

\section{Questionnaire \& Scale}

The range used by Davenport \& Marchand (1999) was implemented to measure the leadership of the company. The statistic range of leadership contains four products. The statistic range for culture was implemented from the research of Liao (2010). The societies in the company were measured through three products statistic range. The statistic range for technological innovation was used from the research of Kostova \& Roth (2002). Six products statistic range was used for the statistic of technological innovation. The research device consists of elements to cover information of workers in the given industry. Each item was calculated on the five-point Likert range varies from highly disagree (1) to highly agree (5).

\section{RESULTS}

The results of the table indicate that knowledge management practices have a significant impact on competency development of the organization and account for $100 \%$ amplification in the competency development of the organization. The critical ratio exhibits that knowledge management practices in an important determinant of competency development of the organization.

TABLE 1

Regression Weights

\begin{tabular}{lcc}
\hline & C.R. & P-value \\
\hline Leadership & 6.790 & 0.000 \\
Culture & 9.733 & 0.000 \\
Competency & 6.555 & 0.000 \\
Development & & \\
Technology & 12.65 & 0.000 \\
\hline
\end{tabular}

The results of the table further reveal that knowledge management practices have a positive impact on technology in the organization. Knowledge management practices report $11 \%$ intensification in technology. The high critical ratio of knowledge management practices divulges that it is an important factor of technology in organization. The results of the table indicate that knowledge management practices have a significant impact on culture of the organization and account for $77 \%$ amplification in the culture of the organization. The critical ratio exhibits that knowledge management practices is an important determinant of culture in the organization.

Similarly, the results further reveal that knowledge management practices have a positive impact on leadership in the organization. Knowledge management practices report $98 \%$ intensification in leadership. The high critical ratio of knowledge management practices divulges that it is an important factor of leadership in organization

TABLE 2

Regression Weights

\begin{tabular}{lccc}
\hline & S.E. & C.R. & P \\
\hline $\begin{array}{l}\text { Organizational } \\
\text { Performance }\end{array}$ & 0.031 & 26.106 & 0.00 \\
\hline
\end{tabular}

The results of the Table 2 indicate that knowledge management practices have a significant impact on organizational performance in the organization and account for $81 \%$ amplification in the organizational performance in the organization. The critical ratio exhibits that knowledge management practices is an important determinant of organizational performance in the organization.

TABLE 3

Model Fit Summary

\begin{tabular}{lcccc}
\hline & & Estimate & C.R. & P \\
\hline $\begin{array}{l}\text { Organizational } \\
\text { Performance }\end{array}$ & KMP & 0.86 & 20.1 & 0.00 \\
\hline
\end{tabular}

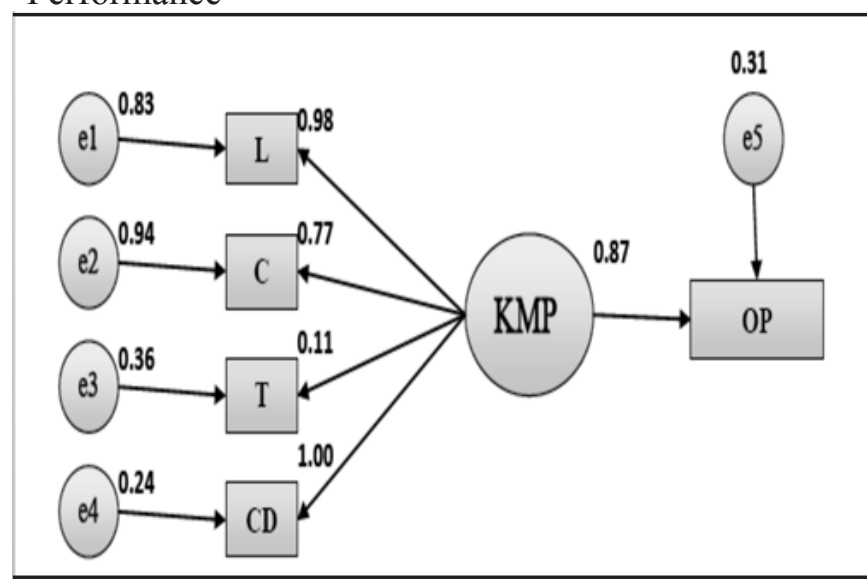


The results of the table designate that knowledge management practices have a significant effect on organizational performance in the organization and account for $86 \%$ intensification in the organizational performance in the organization. The critical ratio exhibits that knowledge management practices is an important determinant of organizational performance in the organization.

\section{DISCUSSION}

This research indicated the resulting value of leadership and leading habits to deal with modern issues of the internal and external environment. Leadership attributes have positive mindset of importance towards dealing with knowledge methods in the company. The leadership is in agreement towards the impact of Knowledge management to effectuate the maintaining of advancement of the company. This research provides position of leadership and its fusing impact on the knowledge rendering. It is significant to innovativeness. Leadership concerns strongly with distribution and cooperation of knowledge to the very impact of the methods of knowledge management in the company. Past studies support the current results of the research and show that leadership affects significantly on the knowledge management methods (Barling, Weber \& Kelloway, 1996; Barling \& Helleur, 2000; Merritt, 2003). Leadership converge the individual's ability to focus on perspective and produces capacity of development and be determined to achieve the competitive advantage and ongoing advancement (Wellins \& Weaver, 2003).

Technological innovation is inevitably required for any company to keep itself aware and make the effort with ongoing international change (Stuedemann, Ardichvili, Maurer, Li, \& Wentling, 2007). Technological innovation infusion becomes a success, and companies exploit it as a significant expense and it was demonstrated by the earlier researches (Davenport et al., 1998; Alazmi \& Zairi, 2003; Artail, 2006; Hasanali, 2002; Hariharan, 2005; Wong, 2005) that KM by means of technology makes it possible for the knowledge management methods.

\section{CONCLUSION}

The study examined how knowledge can be shared within and outside the firm throughout the progression of culture in organization. The culture should bring the organization knowledge and resources and its efficient using of core skills to achieve goals and results. The research divulges a significant connection between leadership and knowledge management methods. It is clear from the research that emotional intelligence plays a huge role in improving leadership in company which in turn contributes better knowledge management methods. This connection enables the company to know about the influence of HR management to accomplish the goals and objectives of company. Business culture is, however, comprehensive and multifarious. It consists of several factors that are created into an organization's environment of norms, values, attitudes, and business meetings (Miller, 1995; Blackler, 2000; Rastogi, 2000; Gupta and Govindarajan, 2000). The materials also present a framework for explaining the connection between culture and Knowledge management methods by realizing that culture is an essential aspect in knowledge management methods. In addition, culture is essential to successful knowledge management method.

\section{Limitations and Future Research}

Even though model of the research is examined and test outcomes of the research are mostly helpful since the participants of the research offered the test information, possibly there would be variations or choices, which may survive due to different personal encounters, family and instructional as well as work-related experience. This research was performed in business and NGO's in the investment places due to time and cost difficulties it would be further improved in different provincial places. Hence, the provided outcomes should be overlooked to incorporate the common case. However, it may provide essential referrals for the companies placed in other places or nations around the world whose conditions are just like those in Pakistan. This research courses towards the long run line to research on the same factors as the consultant market and developing the style with their systems and functions. The move of knowledge and storage with the worried workers at appropriate destinations and individuals outside the company is recommended to aid and obtain further success.

\section{REFERENCES}

Ahmed, S., Fiaz, M., \& Shoaib, M. (2015). Impact of Knowledge Management Practices on Organizational Performance: an Empirical study of Banking Sector in Pakistan. FWU Journal of Social Sciences, 9(2), 147-167.

Alazmi, M., \& Zairi, M. (2003). Knowledge management critical success factors. Total Quality Management and Business Excellence, 14(2), 199-204.

Artail, H. A. (2006). Application of KM measures to the impact of a specialized groupware system on corporate productivity and operation. Information \& Management, 43, 551-564.

Barling, J., Weber, T., \& Kelloway, E. K. (1996). Effects 
of transformational leadership training on attitudinal and financial outcomes: A field experiment. Journal of Applied Psychology, 81(6), 827-832.

Bass, B. M. (1997). Does the transactionaltransformational leadership paradigm transcend organizational and national boundaries? American Psychologist, 52(2), 130-139.

Battor, M., Zairi, M., \& Francis, A. (2008). Knowledgebased capabilities and their impact on performance: a best practice management evaluation. Business Strategy Series, 9(2), 47-56.

Bethel, C. N. (1998). A study of the relationship between presidential leadership orientation and organizational effectiveness in bible colleges (Doctoral dissertation, West Virginia University).

Blackler, F., \& McDonald, S. (2000). Power, mastery and organizational learning. Journal of Management Studies, 37(6), 833-852.

Bohn, J. G. (2002). The relationship of perceived leadership behaviors to organizational efficacy. Journal of Leadership \& Organizational Studies, 9(2), 65-79.

Bontis, N., \& Fitz-Enz, J. (2002). Intellectual capital ROI: a causal map of human capital antecedents and consequents. Journal of Intellectual Capital,3(3), 223-247.

Bowman, C., \& Ambrosini, V. (2003). How the resourcebased and the dynamic capability views of the firm inform corporate-level strategy. British Journal of Management, 14(4), 289-303.

Burns, J. M., \& Leadership, H. (1978). Row. New York, 280.

Cohen, W. M., \& Levinthal, D. A. (1990). Absorptive capacity: A new perspective on learning and innovation. Administrative Science Quarterly, 128152.

Davenport, T. H., De Long, D. W., \& Beers, M. C. (1998). Successful knowledge management projects. Sloan Management Review, 39(2), 43-57.

Dierickx, I., \& Cool, K. (1989). Asset stock accumulation and sustainability of competitive advantage. Management Science, 35(12), 1504-1511.

Gupta, A. K., \& Govindarajan, V. (2000). Knowledge flows within multinational corporations. Strategic Management Journal, 21(4), 473-496.

Hamel, G., \& Prahalad, C. K. (1990). Corporate imagination and expeditionary marketing. Harvard Business Review, 69(4), 81-92.

Hariharan, A. (2005). Critical success factors for knowledge management. Knowledge Management Review, 8(2), 16-19.

Harrison, R. T., \& Leitch, C. M. (2000). Learning and organization in the knowledge-based information economy: Initial findings from a participatory action research case study. British Journal of Management, 11(2), 103-119.

Hasanali, F. (2002). Critical success factors of knowledge management. Retrieved July 1, 2006, from www. providersedge.com/docs $/ \mathrm{km} \_$articles/Critical_ Success_Factors_of_KM.pdf

Heilbrunn, J. (1994). Can leadership be studied? The Wilson Quarterly,18(2), 65.

Holland, J. H., \& Miller, J. H. (1991). Artificial adaptive agents in economic theory. The American Economic Review, 81(2), 365-370.

Kevin Kelloway, E., Barling, J., \& Helleur, J. (2000). Enhancing transformational leadership: The roles of training and feedback. Leadership \& Organization Development Journal, 21(3), 145-149.

Kim, H. S., \& Shim, S. (2003). Gender-based approach to the understanding of leadership roles among retail managers. Human Resource Development Quarterly, 14(3), 321-342.

Kostova, T., \& Roth, K. (2002). Adoption of an organizational practice by subsidiaries of multinational corporations: Institutional and relational effects. Academy of Management Journal, 45(1), 215-233.

Lee, C. K., Tan, B., \& Chiu, J. Z. (2008). The impact of organisational culture and learning on innovation performance. International Journal of Innovation and Learning, 5(4), 413-428.

Lee, Y. C., \& Lee, S. K. (2007). Capabilities, processes, and performance of knowledge management: a structural approach. Human Factors and Ergonomics in Manufacturing \& Service Industries, 17(1), 21-41.

Lewis-Fernández, R., Hinton, D. E., Laria, A. J., Patterson, E. H., Hofmann, S. G., Craske, M. G., ... \& Liao, B. (2010). Culture and the anxiety disorders: Recommendations for DSM-V. Depression and anxiety, 27(2), 212-229.

Li, W., Ardichvili, A., Maurer, M., Wentling, T., \& Stuedemann, R. (2007). Impact of Chinese culture values on knowledge sharing through online communities of practice. International Journal of Knowledge Management (IJKM), 3(3), 46-59.

Lin, C. H., Peng, C. H., \& Kao, D. T. (2008). The innovativeness effect of market orientation and learning orientation on business performance. International Journal of Manpower, 29(8), 752772.

Mahoney, J. T. (1995). The management of resources and the resource of management. Journal of Business Research, 33(2), 91-101.

Malhotra, Y. (1997, August). Knowledge management in inquiring organizations. In proceedings of 3rd Americas Conference on Information Systems (pp. 
293-295).

Mathi, K. (2004). Key success factors for knowledge management. Unpublished master's thesis, Fachhochschule Kempten, Lindau, Germany.

Maxwell, R.C. (1997), Problem-based learning in organizations: a study of self-directed learning instructional technology, and teamwork, unpublished doctoral dissertation, Georgia State University, Milledgeville, GA.

Merritt, W. S., Letcher, R. A., \& Jakeman, A. J. (2003). A review of erosion and sediment transport models. Environmental Modelling \& Software, 18(8), 761799.

Meyer, J. W., \& Rowan, B. (1977). Institutionalized organizations: Formal structure as myth and ceremony. American Journal of Sociology, 340363.

Pounder, J. S. (2001). "New leadership" and university organisational effectiveness: exploring the relationship. Leadership \& Organization Development Journal, 22(6), 281-290.

Quintas, A., Saraiva, M. J. M., \& Brito, R. M. (1999). The Tetrameric Protein Transthyretin Dissociates to a Non-native Monomer in Solution A NOVEL MODEL FOR AMYLOIDOGENESIS. Journal of Biological Chemistry, 274(46), 32943-32949.

Rastogi, P. N. (2000). Knowledge management and intellectual capital-the new virtuous reality of competitiveness. Human Systems Management, 19(1), 39-48.

Rigby, D. (2001). Management tools and techniques: A survey. California Management Review, 43(2), 139-160.

Rigby, D., \& Bilodeau, B. (2005). The Bain 2005 management tool survey. Strategy \& Leadership, 33(4), 4-12.

Rigby, D., \& Bilodeau, B. (2007). Bain's global 2007 management tools and trends survey. Strategy \& Leadership, 35(5), 9-16.

Rollnick, S., \& Miller, W. R. (1995). What is motivational interviewing?. Behavioural and Cognitive Psychotherapy, 23(04), 325-334.

Schein, E. H. (1985). Organizational Culture and Leadership. A Dynamic view. San Francisco, Jossy-Boss.

Schein, E. H. (1992). How can organizations learn faster?: the problem of entering the Green Room.

Seleim, A., \& Khalil, O. (2007). Knowledge management and organizational performance in the Egyptian software firms. International Journal of Knowledge Management (IJKM), 3(4), 37-66.

Teece, D. J. (1998). Capturing value from knowledge assets: The new economy, markets for know-how, and intangible assets. California Management Review, 40(3), 55-79.

Teece, D. J., Pisano, G., \& Shuen, A. (1997). Dynamic capabilities and strategic management. Strategic Management Journal, 509-533.

Thompson, E. P. (1967). Time, work-discipline, and industrial capitalism.Past \& Present, (38), 56-97.

Ulrich, D. (1998). A new mandate for human resources. Harvard Business Review, 76, 124-135.

Vera, D. and M. Crossan(2003). 'Organizational learning and knowledge management: toward an integrative framework'. In M. Easterby-Smith and M. A. Lyles (eds), Blackwell Handbook of Organizational Learning and Knowledge Management, pp. 123141. Oxford: Blackwell.

Verona, G., \& Ravasi, D. (2003). Unbundling dynamic capabilities: an exploratory study of continuous product innovation. Industrial and Corporate Change, 12(3), 577-606.

Wellins, R. S., \& Weaver, P. S. (2003). From c-level to see-level. T AND D,57(9), 58-65.

Wong, K. Y. (2005). Critical success factors for implementing knowledge management in small and medium enterprises. Industrial Management and Data Systems, 105(3/4), 261-279.

Zack, M., McKeen, J., \& Singh, S. (2009). Knowledge management and organizational performance: an exploratory analysis. Journal of Knowledge Management, 13(6), 392-409.

Zahra, S. A., \& George, G. (2002). Absorptive capacity: A review, reconceptualization, and extension. Academy of management review, 27(2), 185-203.

Zollo, M., \& Winter, S. G. (2002). Deliberate learning and the evolution of dynamic capabilities. Organization Science, 13(3), 339-351.

Zott, C. (2003). Dynamic capabilities and the emergence of intraindustry differential firm performance: insights from a simulation study. Strategic Management Journal, 24(2), 97-125. 